\title{
Technological intensity and innovation capability in industrial firms
}

\author{
Paulo Antônio Zawislak and Edi Madalena Fracasso \\ School of Management, Federal University of Rio Grande do Sul, \\ Porto Alegre, Brazil, and \\ Jorge Tello-Gamarra \\ School of Chemistry and Food, Federal University of Rio Grande, \\ Santo Antônio da Patrulha, Brazil
}

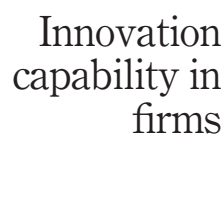

189

Received 28 November 2016 Accepted 26 February 2017

\begin{abstract}
Purpose - Over time, technological intensity has been used as a proxy for innovation capability of firms in an industrial sector. However, not only firms belonging to the stratum of high technological intensity are able to innovate. Therefore, this study aims to explore a potential association between technological intensity and innovation capability in firms from different industrial sectors, using the Organization for Economic Cooperation and Development (OECD)'s classification and the components of innovation capability proposed by Zawislak et al. $(2012,2013)$.
\end{abstract}

Design/methodology/approach - The authors conducted an exploratory research with four case studies focusing on the innovation capability of Brazilian firms.

Findings - The results show that the four firms, each belonging to one stratum of technological intensity, have innovation capability, and the differences regarding this feature can be explained by the balance and development of all firms' capabilities (technological, operational, managerial and transactional).

Originality/value - In the literature, studies that relate technological intensity and innovation capability are scarce. Therefore, the originality of this research is to relate these two concepts. The most important is that firms can be innovative regardless of their stratum of technological intensity, which shows the importance of other capabilities to ensure the innovation's success.

Keywords Firm, Innovation capability, Technological intensity

Paper type Research paper

\section{Introduction}

Technological intensity is defined as the level of knowledge incorporated in companies' products in every industrial sector, and this indicator is typically measured by dividing the

(C) Paulo Antônio Zawislak, Edi Madalena Fracasso and Jorge Tello-Gamarra. Published in Innovation \& Management Review. Published by Emerald Publishing Limited. This article is published under the Creative Commons Attribution (CC BY 4.0) licence. Anyone may reproduce, distribute, translate and create derivative works of this article (for both commercial and noncommercial purposes), subject to full attribution to the original publication and authors. The full terms of this licence may be seen at http://creativecommons.org/licences/by/4.0/legalcode

JEL classification - D23, L6, M2, O3

The authors received financial support from the Research Foundation of the State of Rio Grande do Sul (FAPERGS) and the Brazilian National Council for Scientific and Technological Development (CNPq).

Conflicts of interest: The authors declare no conflicts of interest.

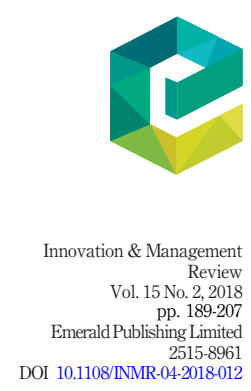


INMR

15,2

average R\&D spending by the firm's revenue. The Organization for Economic Cooperation and Development (OECD) is responsible for the classification of industrial sectors according to their level of technological intensity [Organization for Economic Cooperation and Development (OECD), 2003, 2007]. Through this indicator, it classifies industrial sectors in four levels: high, medium-high, medium-low and low.

Because of OECD's credibility, this classification is used by scholars whenever they need specific information about firms' technological structure and strategic innovation behavior, in different industrial sectors. Moreover, it has been commonly accepted that hightechnology-intensive firms are more innovative, more efficient, pay higher wages and are more successful than low-technology-intensive firms (Hatzichronoglou, 1997; Markwald, 2004).

However, Griliches and Mairesse (1984) found a negative R\&D elasticity in company performance for low- and medium-technology firms (LMTs), while the elasticity for hightech firms (HTs) was positive. Other studies (Kafouros, 2005; Wang and Tsai, 2003) achieved similar results, in which the effect of R\&D activities on firm performance was considerably higher for HTs than for LMTs. In other words, the effect of technological innovation efficiency on firm performance may be less important for LMTs, as their innovations are not usually the result of the latest technological knowledge, but rather rest on their ability to turn different types of knowledge (their general knowledge stock) into innovation (economically useful knowledge) (Bender and Laestadius, 2005). In the same line of thought, Santamaría et al. (2009) found that the quantity of innovation was statistically much larger for HTs than for LMTs.

Based on theoretical arguments and empirical evidence, we arrived at some questions. In high-technology-intensive sectors, all firms should be considered more innovative? Conversely, when a firm belongs to a low-technological intensity sector, should it be considered $a$ priori as less innovative? In other words, do different technological intensity firms show different innovation capabilities?

By asking these questions, we shed light on two issues - technological intensity and innovation capability - that have been constantly studied in the past decades. However, the literature has dealt with them separately. Until now, very few authors (Segarra-Ciprés et al., 2012) have suggested this conceptual relation as we propose.

Most of the studies consider technological intensity as the result of a positive relationship between R\&D spending and revenue, which means that the more high-tech a sector is, the higher will be its performance [Hatzichronoglou, 1997; Organization for Economic Cooperation and Development (OECD), 2003, 2007]. However, this only gives a partial view of how sectoral agents actually behave, that is, which are the innovation capabilities behind companies of a given sector (Hirsch-Kreinsen et al., 2005; Von Tunzelmann and Acha, 2005). Indeed, that relationship does not consider how a company gets and uses its innovation capability and becomes competitive, even in low-technology-intensive sectors.

To identify the innovation capability of firms in different technological intensity stratum, we propose to correlate OECD's typology (which implies different levels of technology mastering for distinct sectors) with the innovation routines and behavior of any firm (its innovation capability) in a specific sector. To do so, we carried out an exploratory case study of four companies, each belonging to an industrial sector whose technological intensity was defined by Organization for Economic Cooperation and Development (OECD) (2003, 2007) typology.

After this introduction, the paper is divided in five sections. Section 2 presents the classification of industrial sectors based on technological intensity, proposed by Organization for Economic Cooperation and Development (OECD) (2003). Section 3 
discusses the different approaches of innovation capabilities, with special emphasis on the innovation capability model proposed by Zawislak et al. (2012, 2013). Section 4 describes the research method. Section 5 presents and discusses the results of the four selected cases, and Section 6 shows the conclusion of the study.

\section{Technological intensity}

In a scenario where competition is fierce and firms struggle to keep and possibly increase their market share, technological level and its evolution play a key role. In this context, firms with high-technological levels would have a potential advantage over those with lowtechnological levels. The acceptance of this assumption has confronted researchers, public administrators and companies' owners and managers with a challenge: after all, what is, in fact, high technology? (Felsenstein and Bar-El, 1989).

Many authors have attempted to answer this question, including Palda (1986), Felsenstein and Bar-El (1989), Hatzichronoglou (1997) and Organization for Economic Cooperation and Development (OECD) (2003, 2007); all of them address high and low technology as parts of the concept of technological intensity.

According to Felsenstein and Bar-El (1989), technological intensity has a multidimensional character consisting of three dimensions, two referring to the industrial inputs (labor and capital) and one to the output (product). The technological intensity of the production factor "labor" relates to the amount of experience and skill levels of the workforce in industry, while the technological intensity of the production factor "capital" regards the quality of capital invested. The product's technological intensity refers to those industries that make large investments for developing new products and processes. At the end, this vision of technological intensity directly relates to the traditional analysis of the ratio between capital and labor, in which the more capital-intensive an industrial sector is, the more technologically intensive it will be, and vice-versa.

Palda (1986) defined technological intensity as the degree to which scientific research efforts contribute to increasing productivity and therefore revenue. Thus, technological intensity could be measured as the ratio between R\&D and the firm's revenue, and not only the capital-labor ratio. The more a firm invests in R\&D, the higher its technological intensity and the higher its revenue[1].

OECD, inspired by these studies, and especially by Hatzichronoglou's (1997), offers a comprehensive classification of technological intensity by industrial sectors, using the concept of technological intensity to take into account both the level of technology specific to the sector (measured by the ratio between R\&D spending and value added) and the technology embodied in acquisitions of intermediate and capital goods. Four groups of industries were identified according to the degree of technological intensity, as shown in Table I.

Although it serves as the basis for defining industrial policies and international trade, various authors have found several limitations in OECD's classification. Hatzichronoglou (1997) highlights an important limitation regarding the classification criterion that emphasizes R\&D. He believes that although R\&D is extremely important for hightechnology industries, it is not that important for other sectors. Attributes such as technical and scientific staff, technology acquired through patents, licenses and know-how and cooperation between companies, among other factors, could also have a significant role when assessing technological intensity.

Moreover, authors like Furtado and Carvalho (2005), Kafouros (2005), Wang and Tsai (2003), Srholec (2007), Santamaría et al. (2009), Mendonça (2009) and Reichert et al. (2016) discuss different versions of technological intensity and firms' behavior, inferring that even 


\section{INMR \\ 15,2}

Medium-high-technology industries

Medium-low-technology industries

\section{Table I.}

Classification of manufacturing industries according to their technological intensity

High-technology industries

Low-technology industries

Source: $\operatorname{OCDE}(2003,2007)$

\section{Technological intensity strata Industries}

(a) Aircraft and spacecraft; (b) Pharmaceuticals; (c) Electronics components (d) Office, accounting and computing machinery; (e) Radio, TV and communications equipment; (f) Medical, precision and optical instruments

(a) Electrical machinery and apparatus; (b) Motor vehicles, (c) Trailers and semi-trailers; (d) Chemicals excluding pharmaceuticals; (e) Railroad equipment and transport equipment; machinery and equipment

(a) Building and repairing of ships and boats; (b) Rubber and plastics products; (c) Coke, refined petroleum products and nuclear fuel; (d) Other non-metallic mineral products; (e) Basic metals and fabricated metal products

(a) Manufacturing, recycling; (b) Wood, pulp, paper, paper products, printing and publishing; (c) Food products, beverages and tobacco, (d) Textiles, textile products, leather and footwear

low-tech sectors may have high-performance firms. This is especially true for developing countries.

However, despite being quite relevant, these criticisms do not affect the essence of OECD's classification, that is, the development of a coherent framework for the analysis of industry's technological structure. Moreover, it has been widely used in recent years, both by academics and policy makers. For all these reasons, OECD's classification makes the necessary stratification, with enough differences between the four groups to suggest the existence of different arrangements of innovation capability.

\section{Innovation capability}

Innovation as a source of firm's advantage is a well-consolidated topic in the literature. However, studies that attempt to identify the sources of innovation are still ongoing. One of the more advanced perspectives is technological capability. As a matter of fact, the different capabilities' approach intends to describe the innovation process that occurs inside the firm boundaries.

These studies began with Katz (1984), Desai (1984), Lall (1992) and Bell and Pavitt (1995), among others. For these authors, innovation is a process that depends only on technological capability. Moreover, they showed a positive association between technological capability, innovation and firm performance.

While technology is a relevant dimension of innovation (Shafia et al., 2016), if we consider innovation exclusively as the outcome of scientific and technological advances, the spectrum of how change and innovation occur in the vast majority of firms is central (Alves et al., 2017). Nevertheless, despite the relationship between technological capability and innovation being positive, several researchers (Teece, 1986; Patel and Pavitt, 1997) observe that, for a firm to be innovative, technological capability is a relevant feature, but not sufficient.

Innovation may be the result of a complex process and depend on a set of capabilities that, although often dispersed throughout the company's structure, can still be aligned with its strategic requirements. This set of capabilities form a meta-capability known as innovation capability. It is the firm's ability to rapidly introduce new products and adopt 
new processes, which are critical for competing with other firms (Guan and Ma, 2003; Wang et al., 2008).

Innovation capability has been studied by using three approaches: assets (Christensen, 1995), processes (Chiesa et al., 1996; Burgelman et al., 2004) and abilities (Guan and Ma, 2003; Yam et al., 2004). Further studies have evolved to consider it as the result of a set of complementary capabilities (Wonglimpiyarat, 2010; Forsman, 2011).

This complementarity is, in fact, the combination of the aforementioned technological driver with the firm's business driver. In other words, the firm is viewed as a technological set of products and processes that operate under a specific business model, to trade and profit from the market. Therefore, as suggested by Zawislak et al. (2012, 2013), every firm has the following general capabilities to some extent: technological, operational, managerial and transactional capabilities (Figure 1).

\subsection{Technological capability}

Technological capability refers to the skills, knowledge, experience and routines that the firm needs to develop new products (goods and/or services). Technological capability concerns directly R\&D activities, which facilitate the creation of new products. This capability is composed of monitoring technological advances, assimilating new technologies and formalization of the development process.

Technological monitoring means that leading firms in their respective industries are able to monitor the range of technological options available in the external environment, thus identifying and choosing the most appropriate technology for their needs (Rush et al., 2007). Once the existing technologies have been identified, firms need to select and bring them inside. This process of assimilating technologies occurs in two ways, through acquisition or learning (Wong et al., 1998). For Christiansen and Varnes (2009), the formalization of the development process suggests that structured approaches for managing the new product development process are fundamental for a successful innovation. These formal rules are part of the best practices in new product development (Griffin, 1997; Davila, 2000).

\subsection{Operational capability}

Operational capability concerns the organization of the production of goods and services on a commercial scale. It has been defined as the skills, knowledge, experience and routines needed to produce goods and services in a flexible way, with quality and at the lowest possible cost. Operational capability is responsible for executing the ideas (products and

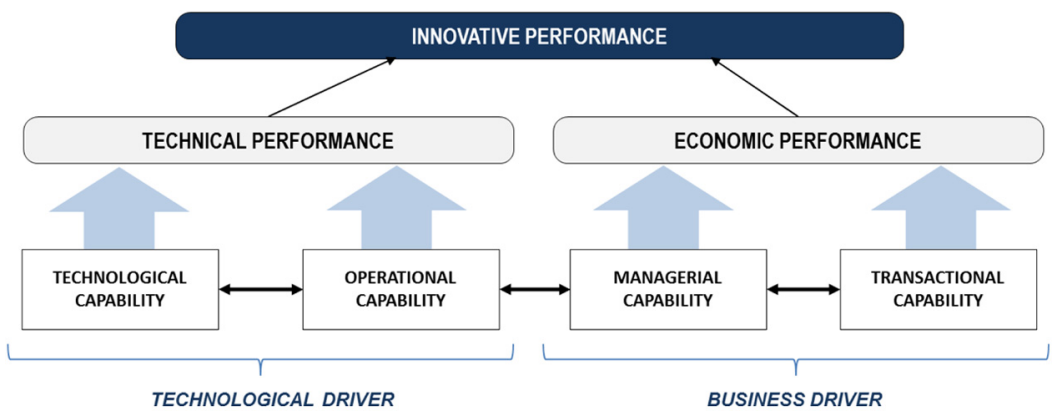

Source: Adapted from Zawislak et al. $(2012,2013)$

Figure 1. Innovation capability 
INMR

15,2

processes) that originate from technological capability. It may be summarized by production planning, the quality system used and the objectives of reducing production costs.

Competition requires that firms seek ways to optimize their production process. Production planning is critical for the refinement of the productive process (Duchessi et al., 1989). In parallel, the quality system "refers to all the physical aspects of the process and the product or service delivered" (Corbett and Wassenhove, 1993, p. 109). The quality of the product or service is closely linked to firm performance and the system designed to achieve it (Capon et al., 1990; Roth and Miller, 1992). Finally, reducing production costs is at the heart of any competing firm. It refers to all direct and indirect costs involved in the production process. Low production costs are positively associated with firm's performance, whether it is an old or a new company (Terjesen et al., 2011).

\subsection{Managerial capability}

Managerial capability refers to the skills, knowledge, experience and routines that a firm uses to efficiently coordinate the capabilities regarding its other activities. This capability also aims to minimize the internal frictions in different areas of the company, and a firm with well-developed management skills can achieve efficiency gains in all areas. Strategy planning, human resources and norms and procedures are the core elements of the managerial capability.

Strategy planning refers to the pattern of decisions made by the firm to define and disclose its objectives, intentions or goals, which creates the main policies and plans to attain them (Andrews, 1980). This is usually applied throughout the firm, while business strategy, being less comprehensive, defines the choice of products or services and individual business markets within the firm (Ansoff, 1965). According to Penrose (1959), a firm is a collection of production assets (human and non-human) under administrative coordination. Resources, particularly human resources, are the essence of firms' growth. For Barnard (1938), companies are organizations that have formal procedures to achieve their goals. A formal organization is a cooperation system among men that is conscious, deliberate and intentional, hence more effective. Norms and procedures are the key to an organization's formalization.

\subsection{Transactional capability}

Finally, transactional capability is defined as a set of skills, knowledge, experience and routines of a firm that allows it to minimize its transaction costs, whether regarding its acquisitions from suppliers or its sales to customers (Tello-Gamarra and Zawislak, 2013). As transactions are a complex activity that goes beyond the simple relationships of buying and selling, this capability refers to gathering information from suppliers and consumers to find the best sources and markets, as well as the most suitable prices (Tello-Gamarra and Zawislak, 2013). In short, a firm's success necessarily involves the ability to place its products on the market, on a commercial scale at the lowest cost. Transactional capability ensures that the firm's path to the market is more efficient through customer relationship, bargaining power and contract management.

Managing customer relationship is critical to firm's success (Reinartz et al., 2004), and establishing actions to enhance this relationship should be a priority task. Programs focused on improving loyalty and affective commitment influence both customer retention and the amount of purchases by each customer (Verhoef, 2003). Bargaining power is the ability to influence the terms and conditions of a contract (with both customers and suppliers) for one's own benefit (Argyres and Liebeskind, 1999). The bargaining power of a firm reduces its transaction costs and its governance structure (Bosse and Alvarez, 2010). According to 
Aoki et al. (1989), the firm is defined as a network of contracts. Therefore, to ensure its existence, it needs to organize a set of contracts (with suppliers and customers) at the lowest possible cost. The contract is a legal instrument used by firms as a safeguard for transactions. These occur both in the acquisition of inputs and in the sale of finished products.

As each of these firm's capability refers to a different set of knowledge and routines that involve different stages of the techno-economic process of adding value, we present in Table II four constructs (one for each capability) with their defining components, that reveal the contours of a firm's innovation capability.

These components were the basis for the analysis of the four case studies of selected firms. Assuming their technological-intensity levels according to Organization for Economic Cooperation and Development (OECD) (2003, 2007), classification and contrasting them to the innovation capability profiles of each firm, it was possible to identify if there is an association between these two constructs.

\begin{tabular}{|c|c|c|}
\hline Capability & Components & Authors \\
\hline $\begin{array}{l}\text { Technological } \\
\text { capability }\end{array}$ & $\begin{array}{l}\text { 1. Technological monitoring } \\
\text { 2. Technology assimilation } \\
\text { 3. Formalization of the } \\
\text { development process }\end{array}$ & $\begin{array}{l}\text { Griffin (1997), Davila (2000), Wong et al. (1998), } \\
\text { Huergo (2006), Rush et al. (2007), Christiansen and } \\
\text { Varnes (2009), Zawislak et al. (2012, 2013) }\end{array}$ \\
\hline $\begin{array}{l}\text { Operational } \\
\text { capability }\end{array}$ & $\begin{array}{l}\text { 1. Production planning } \\
\text { 2. Quality system } \\
\text { 3. Reducing production costs }\end{array}$ & $\begin{array}{l}\text { Duchessi et al. (1989), Capon et al. (1990), Roth and } \\
\text { Miller (1992), Corbett and Wassenhove (1993), } \\
\text { Terjesen } \text { et al. (2011), Zawislak et al. }(2012,2013)\end{array}$ \\
\hline $\begin{array}{l}\text { Managerial } \\
\text { capability }\end{array}$ & $\begin{array}{l}\text { 1. Strategy planing } \\
\text { 2. Human resources } \\
\text { 3. Norms and procedures }\end{array}$ & $\begin{array}{l}\text { Penrose (1959), Barnard (1938), Ansoff (1965), } \\
\text { Andrews (1980), Zawislak et al. (2012, 2013) }\end{array}$ \\
\hline $\begin{array}{l}\text { Transactional } \\
\text { capability }\end{array}$ & $\begin{array}{l}\text { 1. Customer relationship } \\
\text { 2. Bargaining power } \\
\text { 3. Contract }\end{array}$ & $\begin{array}{l}\text { Williamson (1985, 1999), Aoki et al. (1989), Verhoef } \\
\text { (2003), Reinartz et al. (2004), Argyres and Liebeskind } \\
\text { (1999), Bosse and Alvarez (2010), Tello-Gamarra and } \\
\text { Zawislak (2013), Zawislak et al. }(2012,2013)\end{array}$ \\
\hline
\end{tabular}

Table II.

The different components of a firm's capabilities

\section{The method}

A multiple case study was conducted to explore the potential association between technological intensity and innovation capability in firms from different industrial sectors. This research design was chosen because innovation capability is a complex phenomenon, according to the theoretical model presented in Section 3, which is the result of a combination of technological, operational, managerial and transactional capabilities, shown through their components (Table II).

Following Yin's (2003) and Eisenhardt and Graebner's (2007) observations regarding exploratory research, we chose to study four Brazilian companies in industries whose levels of technological intensity followed the Organization for Economic Cooperation and Development (OECD) $(2003,2007)$ classification presented in Table I.

The selected companies, whose names have been replaced by the name of their respective industrial sector, are shown in Table III. These companies were chosen by convenience from a larger research database (Núcleo de Gestão da Inovação Tecnológica [NITEC], 2015). First, because they belong to different sectors and 
INMR

15,2

also because each of them meets the major features that represent the distinct technological intensities, which should lead to different innovation capability arrangements.

\begin{tabular}{|c|c|c|c|c|c|}
\hline \multirow{2}{*}{196} & Technological intensity & Company & Main product & No. of employees & Market \\
\hline & High & Electronics & Capacitors & $1,700 *$ & International \\
\hline Table III. & Medium-high & Chemicals & Thermoplastic resins & $1,600 *$ & International \\
\hline Characteristics of & Low technology & Textiles & Sportswear & $120^{* * *}$ & National \\
\hline
\end{tabular}

We collected data in four stages. First, from secondary sources (information in firms' websites, articles, annual reports, etc.), before the visits and interviews, to understand each firm's behavior.

Second, we carried out in-depth interviews with professionals that had an extensive knowledge of the business, such as the owners, CEOs or directors. We used a semistructured questionnaire (Appendix) derived from the distinct components of each innovation capability (as shown in Table II), according to the conceptual model by Zawislak et al. (2012, 2013). These interviews were scheduled in advance and were recorded. Before starting to record, we told the interviewee that data would be treated with confidentiality, without disclosing the companies' names.

Third, we visited the companies' facilities. During the visits, we collected further information on issues that were not fully covered during the interviews. The visits were guided by the interviewees, and we could know the different areas of the company and observe the existence of the four aforementioned capabilities. In addition, we asked more questions about the firm's behavior regarding innovation capability.

Shortly after interviewing and visiting the firms, we wrote visit reports that followed the same structure of the research instrument, as part of the fourth stage. We also looked for additional secondary information to provide a more complete picture of the firms and their capabilities.

The four capabilities of the companies listed in the reports are presented in the Results section. Each of the results was evaluated based on the level of each component of the four capabilities, according to a consensual judgment by the three authors.

We defined the scores based on the triangulation of the collected information, through an exhaustive review of secondary data prior to the interviews, the recorded interviews (with directors, CEOs or owners), data collection during visits to the factories and additional secondary data gathered after the interviews. From this set of information, we defined three scores: high, medium and low. As firms had, in principle, the four capabilities, and each capability was formed by three components, we evaluated each of these components according to the following criteria:

(1) High (score: 3): When the firm's component exists and is visibly developed. For example, regarding the technological monitoring component, if the firm has a vast collection of routines that indicate that it monitors new technologies within the sector. 
(2) Medium (score: 2): When the component exists but is moderately developed. For technological monitoring, if the firm has some routines for doing it.

(3) Low (score: 1): When the component of the firm is scarce or does not exist; if the firm has few or no technological monitoring routines.

The following section presents the results and discussion, which are organized according to each firm's capability, which, in turn, are made up of three components, as presented before.

\section{Results and discussion}

We present and discuss the results based on the scores of each of the four capabilities that compose the innovation capability as shown in Table II.

We carried out an analysis of each capability and its components. Thus, we made parallel evaluations of the four capabilities in all firms, in each stratum of technological intensity. At the end of the scores' description for each type of capability and intensity, we provide a summary of the association between technological intensity and innovation capability. Table IV, at the end of this section, helps to summarize the scores of each company and its innovation capability.

\subsection{Technological capability}

5.1.1 Technological monitoring. The four firms claimed to monitor new technologies. For example, when asked about the attributes of the firm's technological capability in relation to such monitoring, the interviewee from Textiles commented:

[...]. We travel abroad, at least three times a year to Paris, New York or London, looking for technology. Today the world is flat, and with the internet you can see the windows across the country, you can search for fashion, and observe what's new. So, before looking into magazines, soap operas and customers [... ] today it's important to subscribe to websites, because through the computer you can travel everywhere! So, we mix these travels increasingly, to open our horizons and see what's happening out there [...].

5.1.2 Technology assimilation. In the four firms, all interviewees claimed to assimilate technologies for the business. However, each firm does it in different ways - by purchasing the technology or developing its own. For example, the interviewee from Metal Products company, which corresponds to the medium-low technological intensity stratum, first made the following comment: "So, with the evolution of the company, its technology has changed a lot compared to a few years ago". Further on he continued: "Today, the machinery that we have in the assembly line, with computer numerical control (CNC) machines together with conventional ones, makes up a structure that hardly any competitor has".

5.1.3 Formalization of the development process. The interviewees from the four firms, regardless of their technological intensity stratum, claimed to keep records of the development process of their products. However, there are different levels of formalization. While Chemicals has a complex software to monitor the whole process of new products' development, Textiles conducts several routine activities in search of new information to help the development process. When referring to the formalization of the firm's development process, the Metal Products interviewee commented:

So, this is how we develop the process: we have at least one electrical engineer (who knows everything about electronics), a production engineer, a mechanical engineer (who understands of mechanical assemblies, belts, gears, pulleys, shafts, various types of materials, their hardness, who can help develop the product). Then we have 2 to 4 technicians, who work based on their 
INMR

15,2

198

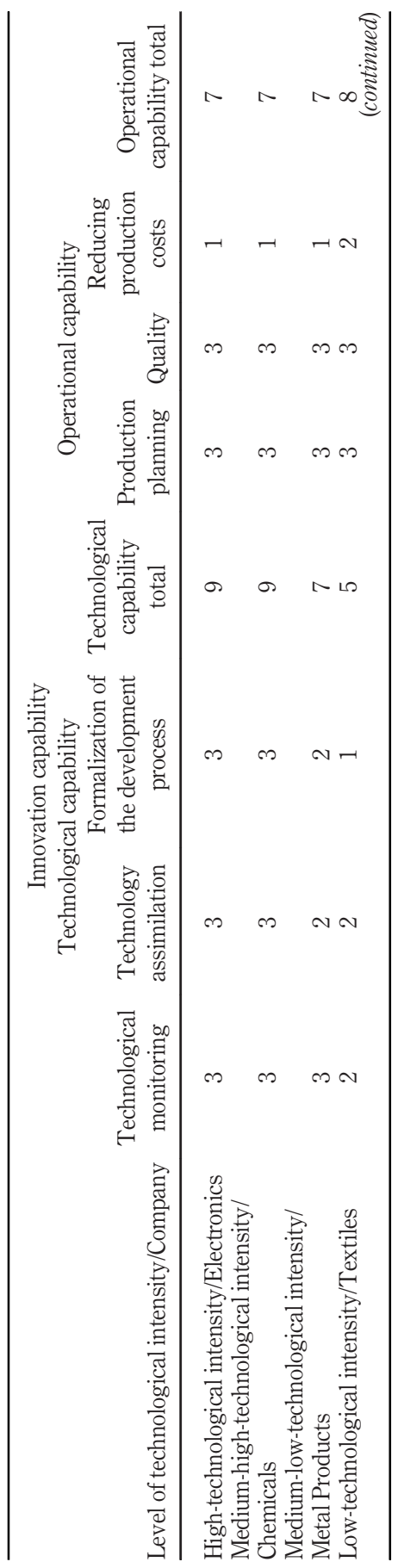

Table IV.

Levels of technological intensity and innovation capability of four firms in Rio Grande Do Sul Brazil 


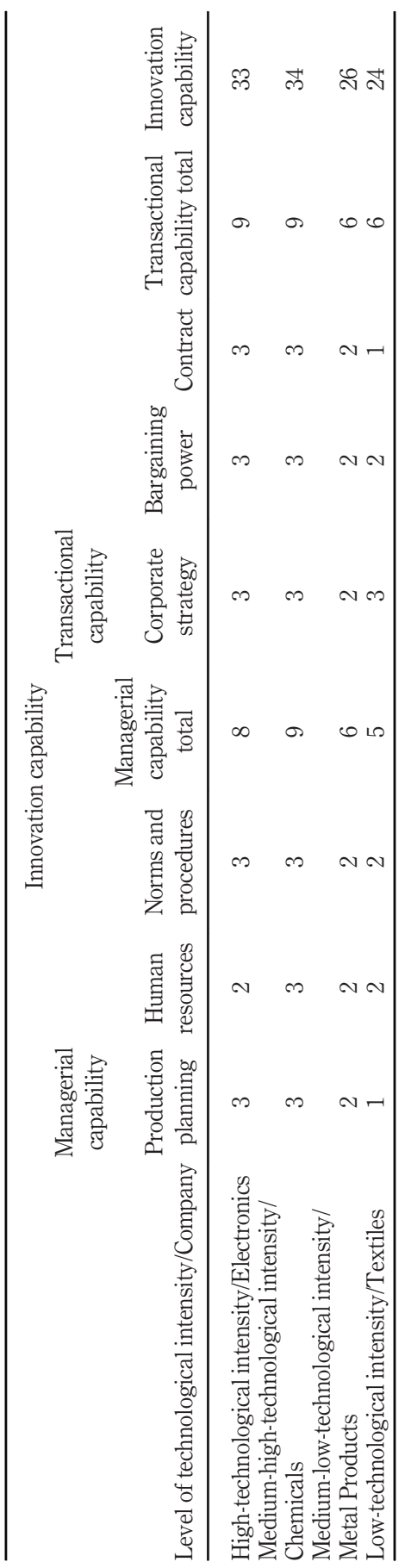

Innovation capability in firms 
INMR

15,2

knowledge, their experience [...]. Since we are always doing different things and sometimes there is no time to set a big meeting, we have short meetings of just a few minutes with the operators, who will produce the piece, modify it, etc., often in the production area. We also have a designer in the group, to help develop a unit or a part.

\subsection{Operational capability}

5.2.1 Production planning. Production planning was found to be present in the four firms, with some specific features in each one, such as the level of formalization, planning time, dependence on inputs, optimization of equipment use, production start and planning meetings. Regarding production planning, Electronics' interviewee said:

Our production strategy is to use the equipment at its maximum capacity. To do that, we focus on having qualified people, and this group is quite restricted. Today, we prefer people graduated in Engineering and Administration. We focus especially on the Theory of Constraints, on the bottlenecks, so we can use the resources at their best. In the factory, there are daily production meetings around this "board" [...] what and how was the production the previous day at each position within the factory; how many pieces were produced; what was the waste; were there any problems with quality? So, these meetings of twenty minutes, half an hour at most, are attended by team leaders, supervisors, technicians, engineers, managers, everyone around the "board".

5.2.2 Quality system. Regarding this issue, all interviewees stressed their companies' commitment to product quality. Quality is considered as an "admission ticket" to their respective sectors. Firms believe that having high-quality standards is more than a matter of choice, it is the minimum requirement for competing.

Electronics' interviewee said:

Our company has always developed all its raw materials. As quality is our main focus, we need raw materials that will lead to quality products. So, we established verticalization precisely in the quality division, in order to have products with the highest quality.

In turn, Metal Products' interviewee, when asked about the firm's main policy, replied:

The issue of quality! First, due to the machinery we have in the production line today, which many of our competitors do not possess. Thus, they cannot achieve better quality, earn as much per piece, dedicate the same time as we do to each part, pass it through several stages until it reaches a final quality. Our quality control inspects every piece (there are tolerance limits regarding threads, gauges, depth), and if any item is outside the standards, which doesn't comply with what was required by the design, it is rejected. The product is reworked or it's considered useless. And a new one is made.

The interviewee from Chemicals said: "[...] quality control checks the properties to see if they meet the product specifications; if so, it is packed and sent for sale". Textile representative stressed: "We don't worry about the price, we worry about quality. For us it is very clear! [...]. We start out from this principle: quality".

5.2.3 Reducing production costs. Of the four firms, only one, Textiles, said it has a policy for cost reduction. The other three (Electronics, Metal Products and Chemicals) commented that their production costs were high. Electronics' interviewee mentioned:

Our costs are higher. They are higher because we have some disadvantages compared to our competitors. The first relates to the workforce, which is more expensive in Brazil than abroad. The cost of an operator in Brazil is higher than in Hungary. The cost of an engineer in Brazil is almost 1.5 times that of Hungary. These costs are a considerable weight. Another problem regards our raw materials, of which 95 per cent come from Asia or Europe. In fact, our raw 
material is from Asia. For us, it is very expensive compared to our competitors. And it is due to transportation costs.

Metal Products' interviewee said:

I believe our costs are a little higher. Today, I don't know exactly what percentage they would be, but our work hour costs a little more than that of the competition.

\subsection{Managerial capability}

5.3.1 Strategy planning. The four firms have established strategies, expressed in different ways; either in terms of the market, as is the case of Electronics; as a result of an activity (quality), as is the case of Metal Products; in terms of defined terms, as in the case of Chemicals; or the focus on activity, as in Textiles.

Electronics' strategy was described as follows:

Our company wants to be the market leader, the number one in the market, and feels that the Asian market has become small for it. Our competitors are also expanding to other areas. That is why we bought this unit in Brazil, because we were seeking to buy another company that was already strong in a market where we wanted to grow.

Regarding its strategy, Metal Products interviewee said: “[...]. There are several, but the main thing is to keep the company's standard of quality, through quality management, cost management, and process management".

For Chemicals, strategy requires a period:

There is always a planning cycle for the next five years. We review the planning cycle and the strategy each year, but the strategy horizon is ten years and the the planning cycle horizon is five years.

On the other hand, Textiles mentioned:

We have been structuring ourselves, automating the company, since the beginning of 2006 . Everything is automated. Our parts are tracked down. From the moment we thought about it, there was a need to cut costs immediately. We are prepared for the new Brazil that is emerging. And we know there will be much competition ahead. So, for us this is the company's strategy.

5.3.2 Human resources. With regard to human resources, the four companies confirmed their key role. However, two of them gave greater emphasis to the importance of employees for the company. The employee is not seen as a production factor to be simply allocated, but as a key contributor to the company, who must develop along with the company. That is, the firms need to grow, while ensuring the development of their employees. Chemicals' interviewee commented:

I would say that the major concern of the company, today, is that it will continue to grow, face a lot of opportunities, so how does the company grow? Through people. Since we have a culture based largely on people, to sustain our growth we must have outstanding people, well informed and with an entrepreneurial profile. I think the challenge is to attract and keep the right people aligned with our culture, with good training, and help the client grow the way we are growing.

Metal Products' interviewee said that training employees is very important, that it is an advantage over the competition. Further on, he said:

[... .] when faced with more difficult products or services, our customers or even competitors look for us, because they are not capable to do, they do not have the machines, the training or the personnel for that, so we do the development for them. 
INMR

15,2

202
5.3.3 Norms and procedures. Regarding this component, all four companies highlighted different features of their norms and procedures that help to formalize daily work.

For example, Metal Products said: "For each production stage within each area of the company, we have procedures and evaluation criteria". This same firm commented on its production process: "We have a schedule for production and an engineering room where I put all the production schedules, with all the customers, within one month". Regarding these items, Chemicals indicated a high degree of formalization.

Of the four companies, what draws most attention is the low-technological intensity stratum. The Textiles firm states that its different areas are planned, and information flows through a managerial system. Moreover, this firm attempts to control all its areas. The interviewee said that:

Today our company is still a family business [... ] but things are very well organized, even in the administrative areas, specifically finance, accounting [...]. We have outside firms that do the accounting, but everything is shown in our system.

And adds:

Everything is in the system [ . . . It was developed in 2007 [ . . . since then we have made changes that today help the general control of production and sales; it is not closely linked to marketing, which is done separately, but internally, we are 100 per cent led by the control system, everything goes through it.

\subsection{Transactional capability}

5.4.1 Customer relationship. The four companies carry out activities designed to keep a good customer relationship and loyalty. Opposite to what we previously thought, both firms of the high- and medium-high-technological intensity strata attempt to keep a good relationship with their customers. That is, even though these firms belong to the highest strata of technological intensity, they do not neglect the attributes regarding customer relationship. For example, Electronics' interviewee commented:

In our case we have a marketing center in Germany. And this marketing center is the main contact with our corporate customers. For example, if I have a big client in Germany, and he is developing a project, he calls us during the development stage (as he also calls our competitors) and we provide technical and commercial support at the same time. But the solution is not given (obviously) by the central, it comes from all over the world. So the engineering staff is always involved with it, and always visits clients. It is part of our daily functions to visit and work with customers at their facilities, to carry out the commercial and technical tasks. We make a lot of visits to clients. And these visits may be everywhere in the world, so to speak. And we have this focus, to try to understand what our customer will need in the future.

Concerning this same issue, Chemicals' interviewee said:

The head of the hierarchy is the customer. It is the client who drives our actions. So, we have to understand his needs and then bring him into the company.

5.4.2 Bargaining power. Regarding this component, the four firms state that they have bargaining power with both customers and suppliers. This finding strengthens the idea that transactional capability is present in all strata of technological intensity. To illustrate it, we present comments made by Textiles interviewee, who theoretically would be the firm with the lowest bargaining power. He says: "we don't change a supplier because of a few reals (Brazilian currency) on some raw material, we negotiate with him over the price". 
5.4.3 Contract. In relation to contracts, three of the four firms put great emphasis on this activity - Electronics, Chemicals and Metal Products - whereas Textiles gives less importance to this transactional aspect. Electronics' interviewee said: "Today our contracts with customers have a failure rate of 1 per million. This is our goal and we achieve it".

It should be noted that contracts depend on several aspects, among them is the business area, as in some sectors, the use of contracts is more common than in others. On this subject, Metal Products' interviewee emphasized: "We sign the contract directly with the customer, only after that we start to work".

Innovation capability in firms

203

\subsection{The association between technological intensity and innovation capability}

Table IV summarizes the main results of this exploratory study. Four companies were chosen from the strata of technological intensity attributed to their respective industrial sectors, according to classification of Organization for Economic Cooperation and Development (OECD) (2003, 2007). The innovation capability of each company was assessed based on the sum of its components, that is, the firm's technological, operational, managerial and transactional capabilities.

We observed that both the Electronics and Chemicals companies that belong to the highand medium-high-technological intensity strata have high levels of innovation capability. On the other hand, the Metal Products company, from the medium-low-technological intensity stratum, has a level of innovation capability similar to that of the Textiles company, which belongs to a low-technological-intensity stratum, as seen in Table IV.

However, the association between technological intensity and innovation capability is weak. Because firms belonging to strata of low-technological intensity also have the innovation capability. Differences between firm's innovation capability may be a consequence of other aspects (e.g. development of other capabilities and scale firm).

\section{Conclusion}

Technological intensity is measured by the ratio of R\&D spending to firm's revenue in different industries and was developed by the OECD to classify different industrial sectors, in developed countries, in four levels: high-, medium-high-, medium-low- and lowtechnological intensity.

Many innovation studies focus exclusively on high-technology companies that tend to be innovative. This led to the assumption that firms from low-technological intensity strata are not innovative.

Our research, which consisted of an exploratory case study of four companies, each belonging to one of the four strata of technological intensity developed by OECD, and the components of innovation capability contained in the model by Zawislak et al. (2012, 2013), were used to identify the level of innovativeness of the four companies.

The aim of this article was to find whether there is an association between technological intensity and innovation capability. However, the association between technological intensity and innovation capability is weak. Thus, the main result is that firms of the four strata of technological intensity have innovation capability. Although firms with the highest technological intensity have a greater innovation capability, firms of the low-tech strata also have it. Therefore, firms can be innovative regardless of their stratum of technological intensity, which shows the importance of other capabilities to ensure their performance.

We believe that the greater innovation capability of some firms is not necessarily because of their technological intensity. These firms have previously accumulated other capabilities (technological, operational, managerial and transactional) regardless of the stratum of technological intensity to which they belong. This accumulation of capabilities allows them to 
INMR

15,2

204

achieve scale and grow in others markets. Coincidentally, in this study, firms that have the greatest innovation capability are big companies with factories in several countries (Table III).

Although it is possible to notice differences in the arrangement of capabilities, according to the sectors' level of technological intensity, the four Brazilian companies show some homogeneity, that is, there are no substantial differences between the capabilities of the sectors.

This research has some limitations that provide an opportunity for future studies. To this end, we suggest a survey with a much larger sample of companies, if possible representing the whole population of firms, through a quantitative study that measures the technological intensity of the sample, as well as the intensity of each component of the four capabilities that comprise innovation capability. In addition, sectoral analyses could be done, to seek different features that can justify innovation capability other than technological intensity.

\section{Note}

1. Palda (1986) advises to be careful when using the term "high technology", since it has a very popular and positive meaning for a firm or industry. Although the terms "high technology" or "high-tech" do not have a simple or precise definition (computers are seen as "high-tech" but atomic reactors are not), they can be considered equal to high technological intensity.

\section{References}

Alves, A., Barbieux, D., Tello-Gamarra, J., Reichert, F. and Zawislak, P. (2017), "Innovation and dynamic capabilities of the firm: defining a model”, Revista De Administração De Empresas, Vol. 57 No. 3, pp. 232-244.

Andrews, K. (1980), The Concept of Corporate Strategy, revised ed., Richard D. Irwin, Homewood, IL.

Ansoff, H.I. (1965), Corporate Strategy: An Analytic Approach to Business Policy for Growth and Expansion, McGraw-Hill, New York, NY.

Aoki, M., Gustafsson, B. and Williamson, O.E. (1989), The Firm as a Nexus of Treaties, Sage Publications, London.

Argyres, N. and Liebeskind, J. (1999), "Contractual commitments, bargaining power, and governance inseparability: incorporating history into transaction cost theory", Academy of Management Review, Vol. 24 No. 1, pp. 49-63.

Barnard, C. (1938), The Functions of the Executive, Harvard University Press, Cambridge.

Bell, M. and Pavitt, K. (1995), “The development of technological capabilities”, in U1 Haque, I. (Ed.), Trade, Technology and International Competitiveness, The World Bank, Washington, DC, pp. 69-101.

Bender, G. and Laestadius, S. (2005), "Non-science based innovativeness: on capabilities relevant to generate profitable novelty", Perspectives on Economic, Political and Social Integration, Vol. 11 Nos 1/2, pp. 123-170.

Bosse, D. and Alvarez, S. (2010), "Bargaining power in alliance governance negotiations: evidence from the biotechnology industry", Technovation, Vol. 30 Nos 5/6, pp. 367-375.

Burgelman, R., Maidique, M.A. and Wheelwright, S.C. (2004), Strategic Management of Technology and Innovation, McGraw Hill, New York, NY.

Capon, N., Farley, J.U. and Hoenig, S. (1990), "Determinants of financial performance: a Meta-analysis”, Management Science, Vol. 36 No. 10, pp. 1143-1159.

Chiesa, V., Coughlan, P. and Voss, C. (1996), "Development of a technical innovation audit”, Journal of Product Innovation Management, Vol. 13 No. 2, pp. 105-136.

Christensen, J.F. (1995), “Asset profiles for technological innovation”, Research Policy, Vol. 24 No. 5, pp. 727-745. 
Christiansen, J.K. and Varnes, C.J. (2009), "Formal rules in product development: sensemaking of structured approaches", Journal of Product Innovation Management, Vol. 26 No. 5, pp. 502-519.

Corbett, C. and Wassenhove, L. (1993), "Trade-offs? What trade-offs? Competence and competitiveness in manufacturing strategy", California Management Review, Vol. 35 No. 4, pp. 107-122.

Davila, T. (2000), "An empirical study on the drivers of management control systems' design in new product development”, Accounting, Organizations and Society, Vol. 25 Nos 4/5, pp. 383-409.

Desai, A. (1984), "India's technological capability: an analysis of its achievements and limits", Research Policy, Vol. 13 No. 5, pp. 303-310.

Duchessi, P., Schaninger, C.M. and Hobbs, D.R. (1989), "Implementing a manufacturing planning and control information-system”, California Management Review, Vol. 31 No. 3, pp. 75-90.

Eisenhardt, K. and Graebner, M. (2007), "Theory building from cases: opportunities and challenges", Academy of Management Journal, Vol. 50 No. 1, pp. 25-32.

Felsenstein, D. and Bar-El, R. (1989), "Measuring the technological intensity of the industrial sector: a methodological and empirical approach", Research Policy, Vol. 18 No. 4, pp. 239-252.

Forsman, H. (2011), "Innovation capacity and innovation development in small enterprises. a comparison between the manufacturing and service sectors", Research Policy, Vol. 40 No. 5, pp. 739-750.

Furtado, A.T. and Carvalho, R.Q. (2005), "Padrões de intensidade tecnológica da indústria brasileira: um estudo comparativo com os países centrais”, São Paulo Em Perspectiva, Vol. 19 No. 1, pp. 70-84.

Griffin, A. (1997), "PDMA research on new product development practices: updating trends and benchmarking best practices", Journal of Product Innovation Management, Vol. 14 No. 6, pp. 429-458.

Griliches, Z. and Mairesse, J. (1984), "Productivity and R\&D at the firm level", in Griliches, Z. (Ed.), $R \& D$, Patents, and Productivity, University of Chicago Press, Chicago, pp. 339-374.

Guan, J. and Ma, N. (2003), "Innovative capability and export performance of Chinese firms", Technovation, Vol. 23 No. 9, pp. 737-747.

Hatzichronoglou, T. (1997), "Revision of the high-technology sector and product classification", [Working Paper no 1997/2], OECD Publishing, Paris.

Hirsch-Kreinsen, H., Jacobson, D., Laestadius, S. and Smith, K. (2005), "Low and medium technology industries in the knowledge economy: the analytical issues", in Hirsch-Kreinsen, H., Jacobson, D. and Laestadius, S. (Eds), Low-Tech Innovation in the Knowledge Economy, Peter Lang GmbH, Frankfurt am Main, pp. 11-30.

Huergo, E. (2006), "The role of technological management as a source of innovation: evidence from Spanish manufacturing firms", Research Policy, Vol. 35 No. 9, pp. 1377-1388.

Kafouros, M. (2005), "R\&D and productivity growth: evidence from the UK", Economics of Innovation and New Technology, Vol. 14 No. 6, pp. 479-497.

Katz, J. (1984), "Domestic technological innovations and dynamic comparative advantage", Journal of Development Economics, Vol. 16 Nos 1/2, pp. 13-37.

Lall, S. (1992), "Technological capabilities and industrialization”, World Development, Vol. 20 No. 2, pp. 165-186.

Markwald, R. (2004), "Intensidade tecnológica e dinamismo das exportações brasileiras", Revista Brasileira De Comércio Exterior, Vol. 79 No. 2, pp. 3-11.

Mendonça, S. (2009), "Brave old world: accounting for 'high-tech' knowledge in 'low-tech' industries", Research Policy, Vol. 38 No. 3, pp. 470-482.

Núcleo de Gestão da Inovação Tecnológica (NITEC) (2015), "Caminhos da inovação na indústria gaúcha”, available at: www.ufrgs.br/nitec/wp-content/uploads/2015/12/revista_inova.pdf

Organization for Economic Cooperation and Development (OECD) (2003), Science, Technology and Industry Scoreboard, OECD, Paris.

Organization for Economic Cooperation and Development (OECD) (2007), Science, Technology and Industry Scoreboard, OECD, Paris. 
INMR

15,2

Palda, K. (1986), “Technological intensity: concept and measurement”, Research Policy, Vol. 15 No. 4, pp. 187-198.

Patel, P. and Pavitt, K. (1997), "The technological competencies of the world's largest firms: complex and path-dependent, but not much variety", Research Policy, Vol. 26 No. 2, pp. 41-156.

Penrose, E. (1959), The Theory of the Growth of the Firm, John Wiley \& Sons, New York.

Reichert, F., Torgas, N., Zawislak, P. and Arundel, A. (2016), "Exploring innovation success recipes in low-technology firms using fuzzy-set QCA", Journal of Business Research, Vol. 69 No. 11, pp. 1-5.

Reinartz, W., Krafft, M. and Hoyer, W.D. (2004), "The customer relationship management process: its measurement and impact on performance", Journal of Marketing Research, Vol. 41 No. 3, pp. 293-305.

Roth, A. and Miller, J. (1992), "Success factors in manufacturing”, Business Horizons, Vol. 35 No. 4, pp. 73-81.

Rush, H., Bessant, J. and Hobday, M. (2007), "Assessing the technological capabilities of firms: developing a policy tool”, British Journal Management, Vol. 37 No. 3, pp. 221-236.

Santamaría, L., Nieto, M.J. and Barge-Gil, A. (2009), "Beyond formal R\&D: taking advantage of other sources of innovation in low- and medium-technology industries", Research Policy, Vol. 38 No. 3, pp. 507-517.

Segarra-Ciprés, M., Bou-Llusar, C. and Roca-Puig, V. (2012), "Exploring and exploiting external knowledge: the effect of sector and firm technological intensity", Innovation, Vol. 14 No. 2, pp. 203-217.

Shafia, M., Shavvalpour, S., Hosseini, M. and Hosseini, R. (2016), "Mediating effect of technological innovation capabilities between dynamic capabilities and competitiveness of research and technology organisations", Technology Analysis \& Strategic Management, Vol. 28 No. 7, pp. 1-16.

Srholec, M. (2007), "High-tech exports from developing countries: a symptom of technology spurts or statistical illusion?", Review of World Economics, Vol. 143 No. 2, pp. 227-255.

Teece, D. (1986), "Profiting from technological innovation", Research Policy, Vol. 15 No. 6, pp. 285-305.

Tello-Gamarra, J. and Zawislak, P.A. (2013), “Transactional capability: innovation's missing link”, Journal of Economics, Finance, and Administrative Science, Vol. 18 No. 34, pp. 2-8.

Terjesen, S., Patelb, P.C. and Covina, J. (2011), "Alliance diversity, environmental context and the value of manufacturing capabilities among new high technology ventures", Journal of Operations Management, Vol. 29 Nos 1/2, pp. 105-115.

Verhoef, P.C. (2003), "Understanding the effect of customer relationship management efforts on customer retention and customer share development", Journal of Marketing, Vol. 67 No. 4, pp. 30-45.

Von, T.N. and Acha, V. (2005), "Innovation in low-tech industries", in Fagerberg, J., Mowery, D.C. and Nelson, R.R. (Eds), The Oxford Handbook of Innovation, Oxford University Press, Oxford, pp. 407-432.

Wang, C.H., Lu, I.Y. and Chen, C.B. (2008), "Evaluating firm technological innovation capability under uncertainty", Technovation, Vol. 28 No. 6, pp. 349-363.

Wang, J. and Tsai, K. (2003), "Productivity growth and R\&D expenditure in Taiwan's manufacturing firms [Working Paper no. 9724]”, National Bureau of Economic Research, Cambridge, MA.

Williamson, O. (1999), "Strategic research: governance and competence", Strategic Managerial Journal, Vol. 20 No. 12, pp. 1087-1999.

Williamson, O. (1985), The Economic Institutions of Capitalism, Free Press, New York, NY.

Wong, V., Shaw, V. and Sher, J. (1998), "Effective organization and management of technology assimilation: the case of Taiwanese information technology firms", Industrial Marketing Management, Vol. 27 No. 3, pp. 213-227.

Wonglimpiyarat, J. (2010), "Innovation index and the innovative capacity of nations", Futures, Vol. 42 No. 3, pp. 247-253.

Yam, R., Guan, J., Pun, K. and Tang, E. (2004), "An audit of technological innovation capabilities in Chinese firms: some empirical findings in Beijing, China”, Research Policy, Vol. 33 No. 8, pp. 1123-1140.

Yin, R. (2003), Case Study Research: Design and Methods, Sage Publications, Newbury Park.

Zawislak, P.A., Alves, A., Tello-Gamarra, J., Barbieux, D. and Reichert, F.M. (2012), "Innovation capability: from technology development to transaction capability", Journal of Technology Management \& Innovation, Vol. 7 No. 2, pp. 14-27. 
Zawislak, P.A., Alves, A., Tello-Gamarra, J., Barbieux, D. and Reichert, F.M. (2013), "Influences of the internal capabilities of firms on their innovation performance: a case study investigation in Brazil", International Journal of Management, Vol. 30 No. 1, pp. 329-348.

Innovation capability in firms

\section{Appendix}

Research instrument

- Briefly describe the most important facts in the company's history

- Where does the company's knowledge come from?

- How did the company develop knowledge and the techniques to do what it does?

- How would you compare the company's level of knowledge to its competitors?

- Briefly describe the company's commercial strategy

- Briefly describe the relationship with suppliers and of purchases

- Briefly describe the relationship with customers and of sales

- What makes customers buy from you?

- How do you define your prices?

- What is the company's commercial position compared to its competitors?

- Briefly describe the company's strategy

- Briefly describe the company's administrative processes

- How are the company's costs compared to its competitors?

- Briefly describe the company's productive strategy

- Briefly describe the company's productive process

- How do you compare the company's level of productive efficiency to the competitors?

- Briefly describe the development strategy and decision-making

- Briefly describe the technology development process

- How do you compare the level of the company's development activities to its competitors?

- Give three examples of changes in the company

- Give three examples of company's innovations, and if they were new for the company, for the sector, for the country or for the world

- What kind of outcomes did the innovations cause for the company?

- What is the company's differential advantage to keep it competitive in the market?

- What are the legal/institutional incentives or constraints for the company to innovate?

- Rank in order of importance for innovation the following areas of the company: Technology, Operations, Management and Commercial. Justify your choice.

\section{Corresponding author}

Jorge Tello-Gamarra can be contacted at: jorgetellogamarra@gmail.com

For instructions on how to order reprints of this article, please visit our website: 